\title{
Immunothrombosis and new-onset atrial fibrillation in the general population: the Rotterdam Study
}

\author{
Martijn J. Tilly ${ }^{1}$ Sven Geurts ${ }^{1}$ - Samantha J. Donkel ${ }^{2} \cdot$ M. Arfan Ikram $^{1} \cdot$ Natasja M. S. de Groot ${ }^{3}$. \\ Moniek P. M. de Maat ${ }^{2} \cdot$ Maryam Kavousi $^{1}$ (]
}

Received: 14 June 2021 / Accepted: 3 September 2021 / Published online: 24 September 2021

(c) The Author(s) 2021

\begin{abstract}
Background Atrial fibrillation (AF) is the most common age-related cardiac arrhythmia. The etiology underlying AF is still largely unknown. At the intersection of the innate immune system and hemostasis, immunothrombosis may be a possible cause of atrial remodeling, and therefore be an underlying cause of AF.

Methods From 1990 to 2014, we followed participants aged 55 and over, free from AF at inclusion. Immunothrombosis factors fibrinogen, von Willebrand factor, ADAMTS13, and neutrophil extracellular traps (NETs) levels were measured at baseline. Participants were followed until either onset of AF, loss-to-follow-up, or reaching the end-date of 01-01-2014. Cox proportional hazard modelling was used to calculate hazard ratios (HRs) and 95\% confidence intervals (CIs), adjusted for cardiovascular risk factors.

Results We followed 6174 participants (mean age 69.1 years, 57\% women) for a median follow-up time of 12.8 years. 364 men (13.7\%, incidence rate $13.0 / 1000$ person-years) and 365 women (10.4\%, incidence rate $8.9 / 1000$ person-years) developed AF. We found no significant association between markers of immunothrombosis and new-onset AF after adjusting for cardiovascular risk factors [HR 1.00 (95\% CI 0.93-1.08) for fibrinogen, $1.04(0.97-1.12)$ for von Willebrand factor, 1.00 (1.00-1.01) for ADAMTS13, and 1.01 (0.94-1.09) for NETs]. In addition, we found no differences in associations between men and women.

Conclusion We found no associations between markers of immunothrombosis and new-onset AF in the general population. Inflammation and immunothrombosis may be associated with AF through other cardiovascular risk factors or predisposing conditions of AF. Our findings challenge the added value of biomarkers in AF risk prediction.
\end{abstract}

\section{Graphic abstract}

\section{The association of immunothrombosis with atrial fibrillation}

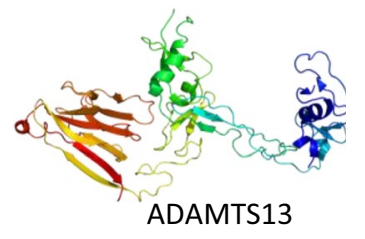

ADAMTS13

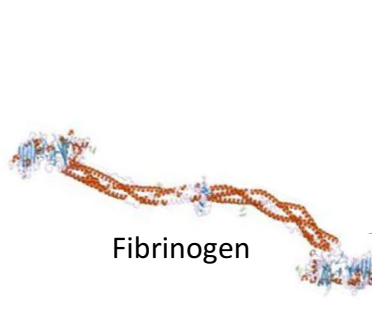

Atrial fibrillation?
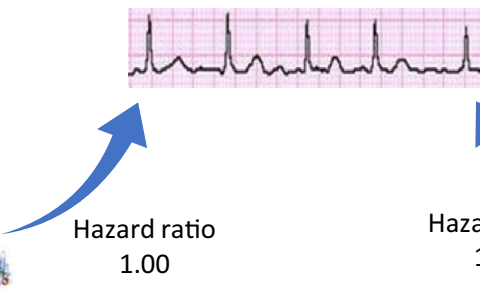
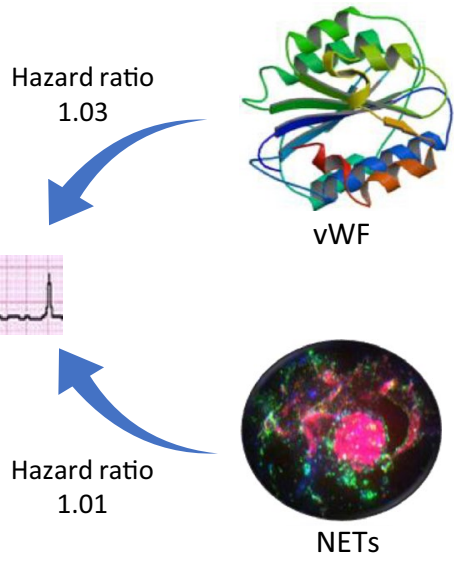

Extended author information available on the last page of the article 
Keywords Immunothrombosis $\cdot$ Atrial fibrillation $\cdot$ NETs $\cdot$ Fibrinogen $\cdot$ Von Willebrand factor $\cdot$ ADAMTS13

\section{Introduction}

Atrial fibrillation (AF) is the most common cardiac arrhythmia of clinical significance [1]. Despite the high prevalence, the etiology underlying AF is still largely unknown. Atrial remodeling is among the pathways promoting initiation and perpetuation of AF [2]. It is hypothesized that inflammation is one of the underlying conditions of atrial remodeling and $\mathrm{AF}[3,4]$.

Immunothrombosis refers to the complex participation of the innate immune system in the formation of intravascular thrombus through distinct cellular and molecular interactions [5-7]. This local coagulation can promote more inflammatory processes, initiating atrial remodeling through direct and indirect tissue damage [3, 4]. Fibrinogen, von Willebrand factor (vWF), and A Disintegrin and Metalloprotease with ThromboSpondin motif repeats 13 (ADAMTS13), a vWF-cleaving protease, are biomarkers that play key roles in coagulation and inflammatory pathways, and may therefore be associated with AF [8-10]. However, prospective research on this is scarce.

Activation of the innate immunity can cause neutrophils to release neutrophil extracellular traps (NETs) $[5,6,11]$. Besides their important role in actively killing pathogens by releasing chromatin and DNA [12], NETs also stimulate coagulation processes by recruiting and activating platelets, binding to tissue factor, and stimulating fibrinogen and $\mathrm{vWF}$ $[5,7,13,14]$. This way, NETs are at the intersection between inflammation and thrombosis, both potentially major players in AF pathophysiology. However, the association of NETs and new-onset $\mathrm{AF}$ has not been investigated.

We aim to investigate the association between markers of immunothrombosis, including fibrinogen, vWF antigen (vWF:Ag), ADAMTS13, vWF:Ag/ADAMTS13 ratio, and NETs, with the risk of new-onset AF among communitydwelling men and women from the large population-based Rotterdam Study.

\section{Materials and methods}

\section{Study population}

A description of the study population is available in Online Resource 1 . Briefly, this study consists of men and women participating in the Rotterdam Study, an ongoing large, prospective population-based cohort study among inhabitants of Ommoord, a suburb in Rotterdam, the Netherlands [15]. We included 6174 participants free of AF at baseline who underwent blood sampling tests for fibrinogen, vWF:Ag, ADAMTS13, or MPO-DNA complex levels (Online Resource 2).

\section{Assessment of markers of immunothrombosis}

Fibrinogen levels were derived from the clotting curve of the prothrombin time assay, using Thromborel S (Behringwerke, Marburg, Germany) on the ACL 300 coagulation analyzer (Instrumentation Laboratory). vWF:Ag levels were measured with an in-house ELISA using polyclonal rabbit antihuman VWF antibodies and horseradish-peroxidaseconjugated antihuman VWF antibodies (DakoCytomation, Glostrup, Denmark) to catch and tag vWF. ADAMTS13 activity was measured in a kinetic assay using Fluorescence Resonance Energy Transfer Substrate VWF 73 (FRETSVWF73), as is thoroughly described in the previous articles $[16,17]$.

We determined NET levels by measuring MPO-DNA complexes with an ELISA as reported earlier [18]. We adjusted the commercial human cell death ELISA kit (Cell death detection ELISAPLUS, Roche Diagnostics Nederland B.V., Almere, The Netherlands). Briefly, as the capturing antibody, we used anti-MPO monoclonal antibody (clone 4A4, ABD Serotec). Patient plasma was added in combination with the peroxidase-labeled anti-DNA monoclonal antibody (from cell death detection ELISA kit; Roche). The absorbance at $405 \mathrm{~nm}$ wavelength was measured using Biotek Synergy HT plate reader with a reference filter of $490 \mathrm{~nm}$. The values are expressed as milli-arbitrary units $(\mathrm{mAU} / \mathrm{mL})$.

\section{Assessment of atrial fibrillation}

AF was defined in accordance with the European Society of Cardiology (ESC) guidelines [1]. At study entry, prevalent $\mathrm{AF}$ and other diseases are assessed by an extensive interview and review of medical records. During the follow-up, participants are continuously monitored through a linkage of the study database with medical records of general practitioners and hospitals. The date of incident AF was defined as the date of the first occurrence of symptoms suggestive of $\mathrm{AF}$ with subsequent electrocardiogram (ECG) verification. At baseline and follow-up examinations, ten second 12-lead ECGs were taken and stored digitally with an ACTA Gnosis IV ECG recorder (Esaote; Biomedical, Florence Italy). All ECGs were analyzed using Modular ECG Analysis System (MEANS), a software system that has been described previously [19]. The ECGs diagnosed by MEANS as rhythm disorder were independently verified by two research 
physicians blind to the MEANS diagnosis. A cardiologist was consulted in case of disagreement. Events of AF were not included if these occurred during the process of dying, or in case of transient AF after cardiac surgery or myocardial infarction (MI). Participants were followed from the inclusion date until date of onset of AF, loss to follow-up, date of death, or January 1st 2014, whichever occurred first.

\section{Assessment of cardiovascular risk factors}

We collected the data on body mass index (BMI), smoking, alcohol use, renal function, differential blood count, hypertension, cardiac therapy, lipid-reducing agents, prevalent coronary heart disease (CHD), heart failure (HF), and diabetes mellitus (DM). A complete description of the assessment of cardiovascular risk factors is available in Online Resource 1.

\section{Statistical analysis}

Baseline characteristics were presented as counts and percentages or mean and standard deviation (SD), or median and inter-quartile range (IQR) in case of skewedness. Incidence rates are presented as events per 1000 person-years (py). Differences between men and women were assessed through Independent Samples T tests, Mann-Whitney $U$ tests, and Pearson's Chi-square tests. Because of skewed distributions, values for fibrinogen, vWF:Ag and MPO-DNA complexes were transformed using the natural logarithm (Ln). Each marker was standardized to obtain hazard ratios (HRs) and 95\% confidence intervals (CIs) per 1-SD increment. We determined the quartiles of fibrinogen, vWF:Ag, ADAMTS13, and MPO-DNA complexes. For fibrinogen, vWF:Ag, and MPO-DNA complexes the first quartiles were used as reference quartile. For ADAMTS13, the fourth quartile was used as reference. To examine the combination of vWF:Ag levels and ADAMTS13 activity on AF incidence, we combined vWF:Ag levels above or below the 75th percentile, and ADAMTS13 activity levels above and below the 25th percentile.

Univariable and multivariable Cox proportional hazards regression analyses were performed. Models were adjusted for age, sex, and cohort (model 1), and additionally for cardiovascular risk factors including: current smoking, alcohol use, estimated glomerular filtration rate (eGFR), hypertension, use of cardiac therapy, use of lipid-reducing agents, prevalent DM, prevalent HF, and prevalent CHD (model 2). HRs and $95 \%$ CIs were calculated to quantify the associations. The proportional hazard assumptions were tested by Schoenfeld residual testing and found to be satisfied. Missing values of covariates (range $0.0-4.9 \%$ ) were imputed under the assumption of missing at random. All available data were used to generate five imputed datasets. The results from each imputed dataset were combined to present single estimates. In addition, analyses were performed in men and women separately.

Statistical significance was considered at two-tailed $p$ value $\leq 0.05$. All analyses and data management were done with IBM SPSS Statistics for Windows, version 25.0 (IBM Corp., Armonk, New York, USA) and R: A language and environment for statistical computing, version 4.0.3 (R Foundation for Statistical Computing, Vienna, Austria).

\section{Results}

\section{Baseline characteristics}

Baseline characteristics are presented in Table 1 . We included 6174 participants (mean age $69.1 \pm 8.2$ years), of whom 3520 (57.0\%) were women. Median blood levels for fibrinogen, vWF:Ag, and MPO-DNA complexes were $3.8 \mathrm{~g} / \mathrm{L}, 1.19 \mathrm{IU} / \mathrm{mL}$, and $53 \mathrm{mAU} / \mathrm{mL}$, respectively. The mean plasma level for ADAMTS13 activity was $91.6 \% \pm 17.7 \%$.

Women were significantly older (mean age $69.6 \pm 8.4$ years vs $68.4 \pm 7.7$ years) and had a higher mean BMI $\left(27.3 \pm 4.4\right.$ vs $\left.26.5 \pm 3.7 \mathrm{~kg} / \mathrm{m}^{2}\right)$, whereas men had significantly higher prevalence of DM (14.9\% vs $11.4 \%)$ and CHD (14.2\% vs $4.0 \%)$. Differential bloodwork showed significant differences for thrombocyte count $\left(241.4 \pm 55.7\right.$ vs $\left.269.4 \pm 57.4 \times 10^{9} / \mathrm{L}\right)$, leucocyte count $\left(7.0 \pm 1.9\right.$ vs $\left.5.7 \pm 1.9 \times 10^{9} / \mathrm{L}\right)$, lymphocyte count $(2.6 \pm 0.9$ vs $\left.2.6 \pm 1.0 \times 10^{9} / \mathrm{L}\right)$, lymphocyte percentage of total leucocytes $(37.5 \pm 7.5$ vs $39.4 \pm 8.0 \%)$, and platelet to lymphocyte ratio $(99.1 \pm 32.3$ vs $111.6 \pm 35.1)$ between men and women, respectively. Median fibrinogen (3.9 g/L [IQR 1.1] for men versus $3.7 \mathrm{~g} / \mathrm{L}$ [IQR 1.1] for women) and ADAMTS13 activity $(94.8 \% \pm 17.6 \%$ for men vs $87.3 \% \pm 16.9 \%$ for women $)$ were significantly different between men and women (Online Resource 3).

\section{Incident atrial fibrillation}

During a median follow-up of 12.8 (IQR 5.6) years (69093py), 729 participants (364 men and 365 women) developed AF (incident rate $10.6 / 1000$ py). Incidence rates were 13.0/1000py for men and 8.9/1000py for women. There were no significant associations between fibrinogen [HR (95\% CI): 1.00 (0.93-1.08)], vWF:Ag [HR (95\% CI): 1.03 (0.95-1.11)], ADAMTS13 [HR (95\% CI): 1.00 (1.00-1.01)], vWF:Ag/ADAMTS13 ratio [HR (95\% CI)): $1.00(0.93-1.08)$ ], or MPO-DNA complexes [HR (95\% CI): 1.01 (0.94-1.09)] with new-onset AF after adjustments (Table 2). 
Table 1 Baseline characteristics of the study population

\begin{tabular}{|c|c|}
\hline & $\begin{array}{l}\text { Total } \\
\text { population } \\
(N=6174)\end{array}$ \\
\hline Age, years & $69.1 \pm 8.2$ \\
\hline BMI $\left(\mathrm{kg} / \mathrm{m}^{2}\right)$ & $27.0 \pm 4.3$ \\
\hline Current smoker, $N(\%)$ & $1247(20.2 \%)$ \\
\hline Prevalent DM, $N(\%)$ & $797(12.9 \%)$ \\
\hline Prevalent CHD, $N(\%)$ & $518(8.4 \%)$ \\
\hline Prevalent HF, $N(\%)$ & $163(2.6 \%)$ \\
\hline Prevalent hypertension, $N(\%)$ & $4163(67.4 \%)$ \\
\hline eGFR $\left(\mathrm{mL} / \mathrm{min} / 1.73 \mathrm{~m}^{2}\right)$ & $74.9 \pm 15.7$ \\
\hline Systolic blood pressure (mmHg) & $143.3 \pm 21.2$ \\
\hline Diastolic blood pressure (mmHg) & $76.8 \pm 11.1$ \\
\hline Blood pressure lowering medication, $N(\%)$ & $2172(35.2 \%)$ \\
\hline Daily alcohol intake $(\mathrm{g})$ & $5.0(17.0)$ \\
\hline Prevalent alcohol abuse, $N(\%)$ & $939(15.2 \%)$ \\
\hline Use of cardiac therapy, $N(\%)$ & $484(7.8 \%)$ \\
\hline Lipid-reducing agents, $N(\%)$ & $812(13.2 \%)$ \\
\hline Thrombocyte count $\left(\times 10^{9} / \mathrm{L}\right)$ & $257.4 \pm 58.3$ \\
\hline Leucocyte count $\left(\times 10^{9} / \mathrm{L}\right)$ & $6.8 \pm 1.9$ \\
\hline Lymphocyte count $\left(\times 10^{9} / \mathrm{L}\right)$ & $2.6 \pm 1.0$ \\
\hline Lymphocyte percentage of leucocytes (\%) & $38.6 \pm 7.8$ \\
\hline Platelet to lymphocyte ratio & $106.3 \pm 34.5$ \\
\hline Total cholesterol (mmol/L) & $5.8 \pm 1.0$ \\
\hline HDL cholesterol (mmol/L) & $1.4 \pm 0.4$ \\
\hline $\mathrm{CRP}(\mathrm{mg} / \mathrm{L})$ & $1.7(3.0)$ \\
\hline Plasma fibrinogen (g/L) & $3.8(1.1)$ \\
\hline Plasma VWF:Ag (IU/mL) & $1.19(0.66)$ \\
\hline ADAMTS13 activity (\%) & $91.6 \pm 17.7$ \\
\hline MPO-DNA complex (mAU/mL) & $53(45)$ \\
\hline
\end{tabular}

Categorical data presented as $N(\%)$

Continuous data presented as mean $\pm \mathrm{SD}$ for normally distributed data, or median (IQR) for skewed distributed data

$B M I$ Body Mass Index, $D M$ diabetes mellitus, $C H D$ coronary heart disease, $H F$ heart failure, $e G F R$ estimated glomerular filtration rate, $H D L$ high density lipoprotein, $C R P$ C-reactive protein, $v W F: A g$ von Willebrand Factor antigen, ADAMTS13 A Disintegrin And Metalloprotease with ThromboSpondin motif repeats 13. Alcohol abuse is defined as $\geq 4$ alcoholic consumptions/day for men, and $\geq 2$ for women

Univariable Cox proportional hazard regression showed a significant larger risk of new-onset AF with higher levels of vWF:Ag in both men [HR (95\% CI): 1.19 (1.07-1.32)] and women [HR $(95 \% \mathrm{CI}): 1.14$ (1.03-1.27)]. After adjusting for cardiovascular risk factors, the associations attenuated (Online Resource 4). For fibrinogen, ADAMTS13, and MPODNA complexes we found no associations in men or women.

Both univariable analysis and multivariable analysis showed no significant differences in risk between quartiles for fibrinogen or MPO-DNA complexes (Fig. 1). We found a
Table 2 Association between markers of immunothrombosis and incident atrial fibrillation in the total population

\begin{tabular}{lcl}
\hline & $\begin{array}{l}\text { Model 1 } \\
\text { HR }(95 \% \mathrm{CI})\end{array}$ & $\begin{array}{l}\text { Model 2 } \\
\text { HR }(95 \% \mathrm{CI})\end{array}$ \\
\hline Fibrinogen (g/L) & $1.02(0.95-1.10)$ & $1.00(0.93-1.08)$ \\
vWF:Ag (IU/mL) & $1.05(0.97-1.13)$ & $1.03(0.95-1.11)$ \\
ADAMTS13 (\%) & $1.00(1.00-1.01)$ & $1.00(1.00-1.01)$ \\
vWF:Ag/ADAMTS13 ratio & $1.02(0.95-1.10)$ & $1.01(0.93-1.08)$ \\
MPO-DNA complex (mAU/ & $1.01(0.94-1.09)$ & $1.01(0.94-1.09)$ \\
mL) & & \\
\hline
\end{tabular}

Presented estimated are hazard ratio (95\% confidence interval) per one standard deviation increase of each immunothrombosis marker

Model 1 is adjusted for age, sex, and Rotterdam Study cohort

Model 2 is additionally adjusted for current smoking, alcohol use, renal function, hypertension, use of cardiac therapy, use of lipidreducing agents, prevalent diabetes mellitus, prevalent heart failure, and prevalent coronary heart disease

$H R$ Hazard Ratio, CI Confidence Interval, $v W F: A g$ von Willebrand Factor antigen, ADAMTS13 A Disintegrin And Metalloprotease with ThromboSpondin motif repeats 13

higher risk of new-onset AF with vWF:Ag levels in the highest quartile as compared to the lowest quartile [HR (95\% CI): 1.37 (1.11-1.70)], and for ADAMTS13 levels in the lowest quartile, as compared to the highest [HR (95\% CI): $1.51(1.23-1.86)]$ in univariable models. After adjustment for cardiovascular risk factors, the associations attenuated (Fig. 1).

In sex-stratified analyses, highest versus lowest vWF:Ag levels showed a significant larger AF risk in women [HR (95\% CI): 1.55 (1.16-2.07)] in univariable analysis, but not in men. In contrast, the lowest versus highest ADAMTS13 activity levels were associated with AF risk among men [HR (95\% CI): 1.63 (1.20-2.22)] in univariable analysis, but not in women. After adjustment for cardiovascular risk factors, the associations were not statistically significant (Online Resource 5).

Combining vWF:Ag and ADAMTS13 levels, participants with vWF:Ag levels $\geq 1.61 \mathrm{IU} / \mathrm{mL}$ and ADAMTS13 activity $\leq 80.31 \%$ had a significantly higher risk of newonset AF than participants with vWF:Ag $<1.61 \mathrm{IU} / \mathrm{mL}$ and ADAMTS13 activity $>80.31 \%$ [HR (95\% CI): 1.47 (1.09-1.98)], albeit nonsignificant after adjustments (Table 2). Sex-stratified analyses showed a larger risk for AF with vWF:Ag levels < $1.61 \mathrm{IU} / \mathrm{mL}$ and ADAMTS13 activity $\leq 80.31 \%$ [HR (95\% CI): 1.55 (1.22-1.97)] in men in univariable analysis, but not in women. After adjustments, all associations attenuated (Online Resource 5).

\section{Discussion}

In this prospective population-based study, we examined the association between immunothrombosis and new-onset AF among men and women. Biomarkers related to inflammation 
Fig. 1 Association between markers of immunothrombosis and incident atrial fibrillation in the total population, per quartile. Adjusted for age, sex, Rotterdam Study cohort, current smoking, alcohol use, renal function, hypertension, use of cardiac therapy, use of lipid-reducing agents, prevalent diabetes mellitus, prevalent heart failure, and prevalent coronary heart disease. Quartiles fibrinogen: $\leq 3.30 \mathrm{~g} / \mathrm{L}$ $3.31-3.80 \mathrm{~g} / \mathrm{L}, 3.81-4.40 \mathrm{~g} / \mathrm{L}$, and $\geq 4.41 \mathrm{~g} / \mathrm{L}$. Quartiles vWF:Ag: $\leq 0.93 \mathrm{IU} / \mathrm{mL}, 0.94$ $1.20 \mathrm{IU} / \mathrm{mL}, 1.21-1.60 \mathrm{IU} / \mathrm{mL}$, and $\geq 1.61 \mathrm{IU} / \mathrm{mL}$. Quartiles ADAMTS13: $\leq 80.31 \%$, 80.32-91.00\%, 91.01-101.75\%, and $\geq 101.76 \%$. Quartiles MPODNA complex: $\leq 42 \mathrm{mAU} /$ $\mathrm{mL}, 42-53 \mathrm{mAU} / \mathrm{mL}, 54-87$ $\mathrm{mAU} / \mathrm{mL}$, and $88 \mathrm{mAU} / \mathrm{mL}$

Total population

Fibrinogen

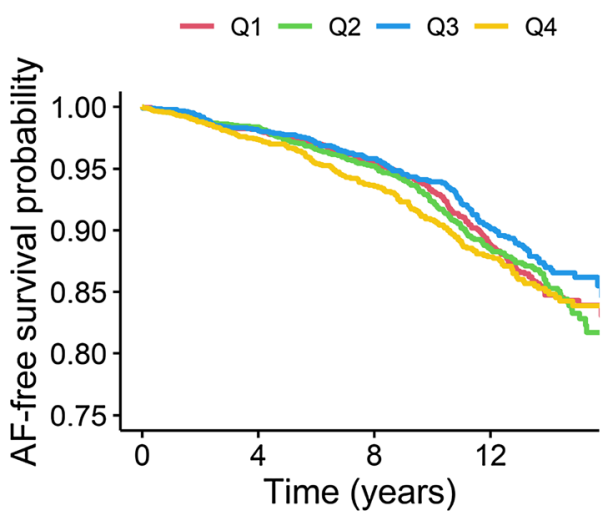

ADAMTS13 activity

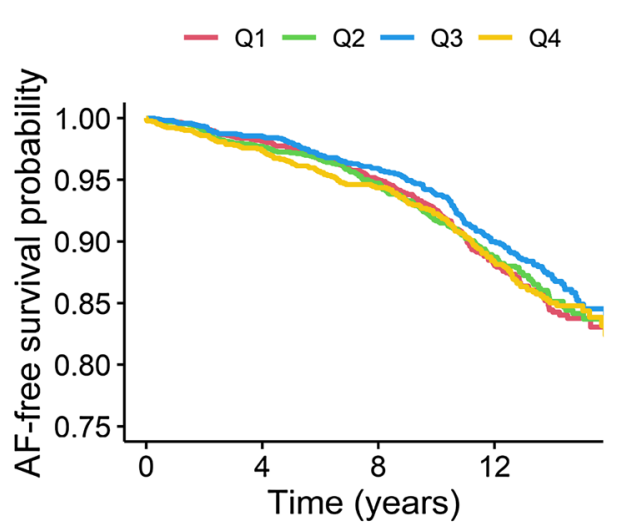

VWF:Ag

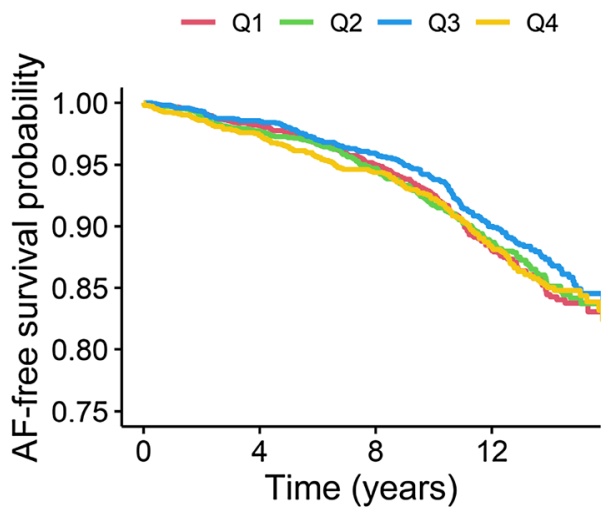

MPO-DNA complex

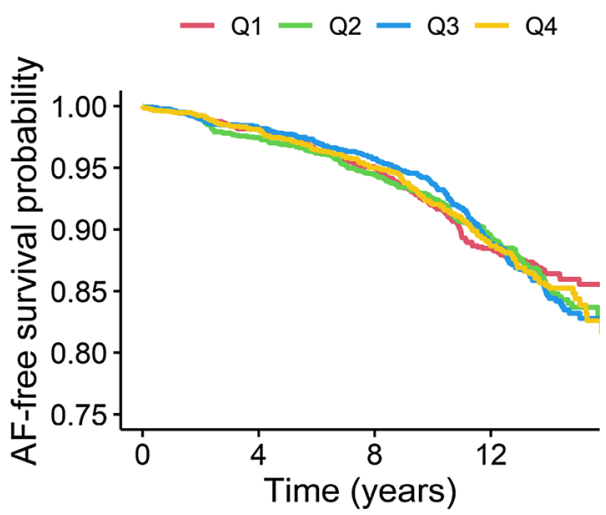

and coagulation, including fibrinogen, vWF, ADAMTS13, vWF:Ag/ADAMTS13 ratio, and NETs were not independently associated with new-onset AF.

This is the first large prospective population-based cohort study to evaluate the link between NET formation and newonset AF development. Previous studies suggested that markers of systemic and local inflammation are associated with AF development [20,21]. While the exact pathways of the development of AF are still unknown, immunothrombosis is implicated in AF pathophysiology. NETs play an important role in immunothrombosis. During the process of NETosis, histones, antimicrobial proteins, and cell-free DNA are released from cells, especially neutrophils [5, 6, 11, 12, 14]. Through Toll-like receptors (TLR) 2, 4, and 9, these histones cause inflammation and eventually cell-death in endothelial and epithelial cells [22]. The histones, as well as the DNA, also directly activate local platelets, which in turn activate the coagulation cascade [22]. Through these processes NETs can cause tissue injury by directly killing endothelial cells and through local microvascular thrombosis. The local tissue damage caused by NETs, combined with the inflammatory effects related to immunothrombosis, can lead to structural and electrical remodeling of the atria [2, 3, 23-28]. This progressively impairs atrial conduction and promote reentry, giving rise to AF [29, 30]. However, the lack of significant associations in our study suggests that the potential impact of inflammation on AF development lies in other pathways than the above-described paths of immunothrombosis. Therefore, more research on the role of immunothrombosis in the development of $\mathrm{AF}$ is required.

Fibrinogen, vWF, and ADAMTS13 play important roles in both coagulation and inflammation, and have been reported as independent risk factors for cardiovascular disease [9, 31-34]. Higher levels of fibrinogen and vWF can lead to intravascular thrombosis, vascular damage, and thrombotic complications, whereas lower levels of ADAMTS13 result in decreased cleavage of large prothrombotic vWF multimers [32]. Nonetheless, we did not find any association between these risk markers with incident AF among women and men from the general population.

Similar to our findings, fibrinogen was not associated with incidence of AF within the Framingham Offspring Study [35] and the Malmö Preventive Study [36]. However, fibrinogen showed significant associations with incident 
AF in the Copenhagen City Heart Study, the ARIC study, and the Women's Health Study [37-39]. Higher levels of fibrinogen may indicate underlying inflammatory processes. Local inflammation may cause local remodeling of the atria, eventually disrupting the conduction, and be a pathophysiological cause of new-onset AF [40]. However, the results regarding the association of fibrinogen with new-onset $\mathrm{AF}$ remain inconclusive. A possible explanation for these discrepancies could be the differences in study populations. The Copenhagen City Heart Study was based on hospitalized AF patients, and therefore possibly represent the most symptomatic and severe AF cases [38]. The ARIC study [37] and the Women's Healthy Study [39] studied younger cohorts. The latter also lacked periodical ECG screening for AF, thus participants with asymptomatic AF or less severe cases of AF may have been missed.

To our knowledge, we are also the first large prospective cohort study reporting on the combination of vWF and ADAMTS13 levels. The ARIC study [37] and the Framingham Offspring Study [41] have reported significant associations between vWF:Ag and AF. vWF is secreted by damaged endothelial cells and plays an active role in thrombogenesis by platelet aggregation [42, 43]. Thrombogenesis can cause further inflammation, cardiovascular complications, and oxidative stress, which can all be underlying causes of AF [44-46]. As ADAMTS13 degrades large, thrombogenic vWF-multimers into smaller and less thrombogenic molecules, an inverse association with AF is expected. A combination of higher levels for vWF:Ag and lower levels of ADAMTS13 may indicate underlying immunothrombosis. None of the previously mentioned studies looked at vWF:Ag and ADAMTS13 combined. The younger age of the participants in the ARIC study may partly explain differences between our results from the ones by ARIC investigators. Ko et al. used proteomics profiling to measure ADAMTS13 levels [41], whereas we measured ADAMTS13 activity using the functional FRETS assay [16, 17]. These different methods might, at least partly, explain different results.

After adjusting for additional cardiovascular risk factors, the observed associations between markers of immunothrombosis and AF attenuated. Possibly, inflammation and immunothrombosis are associated with AF through other cardiovascular risk factors or predisposing conditions to $\mathrm{AF}$, such as CHD or HF. As factors of inflammation and hemostasis were previously associated with cardiovascular disease [31-34], the influence they have on AF initiation might be through these comorbidities. This way, the relation of inflammation and immunothrombosis with newonset AF might be, partly, through other pathophysiological pathways than the direct effect of (local) inflammatory processes and atrial remodeling. In addition, immunothrombosis is a complex conjunction of the immune system and coagulation. Although we aimed to look at different aspects of immunothrombosis in this study, a connection between immunothrombosis and AF might be found through other pathways.

Recent studies have previously challenged the specificity and added value of various biomarkers in prediction of new-onset AF and AF complications [47, 48]. Most studies investigating the association of inflammatory biomarkers use specific patient populations. Therefore, elevated biomarkers may be representing the clinical situation or comorbidities of a patient, rather than actually having a causal relation with the investigated conditions. However, in a large, general population setting as in our current study, single biomarkers may not be specific enough to be of added value for $\mathrm{AF}$ prediction. Moreover, we carefully adjusted our analyses for relevant comorbidities and potential causes of confounding. This supports the notion that many biomarkers could often be a representation of the patient condition. While not investigated in this study, lack of specificity of biomarkers may also hold for the association of immunothrombotic biomarkers related to AF complications [48].

Recent evidence suggests sex differences in AF pathophysiology $[49,50]$. While the incidence of AF is lower in women, women with AF have an increased risk of developing cardiovascular complication and mortality [49]. Sex differences in atrial remodeling and electrophysiological function have been reported [50]. It is known that autoimmune diseases are more prevalent in women, and immunologic differences between men and women have been reported [51, 52]. Also, the role of inflammation in AF initiation may be different in men and women. However, in our study we found no evidence of sex differences in the associations of immunothrombosis with AF.

The large population-based study population and long follow-up are the main strengths of this study. Through extensive interviews by trained interviewers, periodical research center visits, linkage with GP records, and meticulous adjudication of the events by study physicians, AF events are carefully assessed and a range of risk factors are available. However, there are also limitations. Despite the meticulous assessment we are unable to distinguish between paroxysmal and long-lasting AF as Holter monitoring is not available. Additionally, as blood was sampled at baseline, no inferences regarding longitudinal changes in markers and the effect of these changes on AF risk could be made. As our study shows, the development of AF greatly relies on other cardiovascular risks and patient conditions. As biomarkers, as well as many other cardiovascular risk factors, are dynamic, we can expect the evolution of these risk factors as individuals grow older will differ. Future studies investigating these biomarkers, taking into account their dynamic nature through repeated measurements and regular reassessments, are warranted to increase our knowledge regarding the link between $\mathrm{AF}$ and immunothrombosis. 
While representative of the general Dutch population above 55 years old, these results may not apply to men and women of younger age or other ethnicities. Lastly, we determined NET levels by measuring MPO-DNA complexes through ELISA. The specificity of ELISA to accurately detect NETs is controversial, and these results should therefore be cautiously interpreted [53].

\section{Conclusion}

Fibrinogen, vWF:Ag, ADAMTS13, vWF:Ag/ADAMTS13, or NETs were not associated with the risk of new-onset AF in our large prospective population-based study. Our findings challenge the added value of biomarkers in AF prediction in a general population. Inflammation and immunothrombosis may be associated with AF through cardiovascular risk factors or other predisposing conditions to AF. Moreover, the impact of inflammation on new-onset AF could lie in other pathways than the examined immunothrombosis markers. Therefore, more prospective research towards markers of immunothrombosis in AF pathophysiology is warranted.

Supplementary Information The online version contains supplementary material available at https://doi.org/10.1007/s00392-021-01938-4.

Acknowledgements The authors would like to thank all participants of the Rotterdam Study, the staff, and participating general practitioners and pharmacists. The authors would also like to acknowledge J.W.R. van Soerland and F. Dik for their excellent help with the measurement of MPO-DNA complexes.

Author contributions All authors contributed to this manuscript. All authors have read and approved the final manuscript.

Sources of funding The Rotterdam Study is funded by Erasmus Medical Center and Erasmus University Rotterdam, Netherlands Organization for the Health Research and Development (ZonMw), the research Institute for Diseases in the Elderly (RIDE), the Ministry of Education, Culture and Science, the Ministry for Health, Welfare and Sports, the European Commission (DG XII), and the Municipality of Rotterdam. Further support was obtained from the Netherlands Consortium for Healthy Ageing and the Dutch Heart Foundation (2012T008) and the Dutch Cancer Society (NKI-20157737). This project is supported by an Erasmus MC (Mrace) grant. This project is further supported by the Gender and Prevention grant (555003017) from ZonMw. The measurement of MPO-DNA complex levels in participants of the Rotterdam study was supported by a research grant (Prof. Heimburger Award 2018, CSL Behring). The funders had no role in study design, data collection and analysis, decision to publish, or preparation of the manuscript.

Availability of data Data can be obtained upon request. Requests should be directed towards the management team of the Rotterdam Study (secretariat.epi@erasmusmc.nl), which has a protocol for approving data requests. Because of restrictions based on privacy regulations and informed consent of the participants, data cannot be made freely available in a public repository.

\section{Declarations}

Conflict of interest All authors declare no conflict of interest.

Ethics approval The Rotterdam Study has been approved by the Medical Ethics Committee of the Erasmus MC (registration number MEC 02.1015) and by the Dutch Ministry of Health, Welfare, and Sport (Population Screening Act WBO, license number 1071272-159521PG). The Rotterdam Study has been entered into the Netherlands National Trial Register (NTR; www.trialregister.nl) and into the WHO International Clinical Trials Registry Platform (ICTRP; www.who.int/ ictrp/network/primary/en/) under shared catalog Number NTR6831.

Consent All participants provided written informed consent to participate in the study and to have their information obtained from treating physicians.

Open Access This article is licensed under a Creative Commons Attribution 4.0 International License, which permits use, sharing, adaptation, distribution and reproduction in any medium or format, as long as you give appropriate credit to the original author(s) and the source, provide a link to the Creative Commons licence, and indicate if changes were made. The images or other third party material in this article are included in the article's Creative Commons licence, unless indicated otherwise in a credit line to the material. If material is not included in the article's Creative Commons licence and your intended use is not permitted by statutory regulation or exceeds the permitted use, you will need to obtain permission directly from the copyright holder. To view a copy of this licence, visit http://creativecommons.org/licenses/by/4.0/.

\section{References}

1. Fuster V, Ryden LE, Cannom DS, Crijns HJ, Curtis AB, Ellenbogen KA, Halperin JL, Le Heuzey JY, Kay GN, Lowe JE, Olsson SB, Prystowsky EN, Tamargo JL, Wann S, Smith SC Jr, Jacobs AK, Adams CD, Anderson JL, Antman EM, Halperin JL, Hunt SA, Nishimura R, Ornato JP, Page RL, Riegel B, Priori SG, Blanc JJ, Budaj A, Camm AJ, Dean V, Deckers JW, Despres C, Dickstein K, Lekakis J, McGregor K, Metra M, Morais J, Osterspey A, Tamargo JL, Zamorano JL, American College of Cardiology/ American Heart Association Task Force on Practice G, European Society of Cardiology Committee for Practice G, European Heart Rhythm A, Heart Rhythm S (2006) ACC/AHA/ESC 2006 Guidelines for the Management of Patients with Atrial Fibrillation: a report of the American College of Cardiology/American Heart Association Task Force on Practice Guidelines and the European Society of Cardiology Committee for Practice Guidelines (Writing Committee to Revise the 2001 Guidelines for the Management of Patients With Atrial Fibrillation): developed in collaboration with the European Heart Rhythm Association and the Heart Rhythm Society. Circulation 114(7):e257-354. https://doi.org/10.1161/ CIRCULATIONAHA.106.177292

2. Pellman J, Sheikh F (2015) Atrial fibrillation: mechanisms, therapeutics, and future directions. Compr Physiol 5(2):649-665. https://doi.org/10.1002/cphy.c140047

3. Lazzerini PE, Capecchi PL, Laghi-Pasini F (2017) Systemic inflammation and arrhythmic risk: lessons from rheumatoid arthritis. Eur Heart J 38(22):1717-1727. https://doi.org/10.1093/eurhe artj/ehw208

4. Hu YF, Chen YJ, Lin YJ, Chen SA (2015) Inflammation and the pathogenesis of atrial fibrillation. Nat Rev Cardiol 12(4):230-243. https://doi.org/10.1038/nrcardio.2015.2 
5. Engelmann B, Massberg S (2013) Thrombosis as an intravascular effector of innate immunity. Nat Rev Immunol 13(1):34-45. https://doi.org/10.1038/nri3345

6. Gaertner F, Massberg S (2016) Blood coagulation in immunothrombosis - at the frontline of intravascular immunity. Semin Immunol 28(6):561-569. https://doi.org/10.1016/j.smim.2016.10. 010

7. Gould TJ, Vu TT, Swystun LL, Dwivedi DJ, Mai SH, Weitz JI, Liaw PC (2014) Neutrophil extracellular traps promote thrombin generation through platelet-dependent and platelet-independent mechanisms. Arterioscler Thromb Vasc Biol 34(9):1977-1984. https://doi.org/10.1161/ATVBAHA.114.304114

8. Freynhofer MK, Gruber SC, Bruno V, Hochtl T, Farhan S, Zaller V, Wojta J, Huber K (2013) Prognostic value of plasma von Willebrand factor and its cleaving protease ADAMTS13 in patients with atrial fibrillation. Int J Cardiol 168(1):317-325. https://doi. org/10.1016/j.ijcard.2012.09.056

9. Sonneveld MA, Franco OH, Ikram MA, Hofman A, Kavousi M, de Maat MP, Leebeek FW (2016) Von Willebrand factor, ADAMTS13, and the risk of mortality: the rotterdam study. Arterioscler Thromb Vasc Biol 36(12):2446-2451. https://doi.org/10. 1161/ATVBAHA.116.308225

10. Gragnano F, Sperlongano S, Golia E, Natale F, Bianchi R, Crisci M, Fimiani F, Pariggiano I, Diana V, Carbone A, Cesaro A, Concilio C, Limongelli G, Russo M, Calabro P (2017) The role of von Willebrand factor in vascular inflammation: from pathogenesis to targeted therapy. Mediators Inflamm 2017:5620314. https://doi. org/10.1155/2017/5620314

11. Sreeramkumar V, Adrover JM, Ballesteros I, Cuartero MI, Rossaint J, Bilbao I, Nacher M, Pitaval C, Radovanovic I, Fukui Y, McEver RP, Filippi MD, Lizasoain I, Ruiz-Cabello J, Zarbock A, Moro MA, Hidalgo A (2014) Neutrophils scan for activated platelets to initiate inflammation. Science 346(6214):1234-1238. https://doi.org/10.1126/science. 1256478

12. Brinkmann V, Reichard U, Goosmann C, Fauler B, Uhlemann Y, Weiss DS, Weinrauch Y, Zychlinsky A (2004) Neutrophil extracellular traps kill bacteria. Science 303(5663):1532-1535. https:// doi.org/10.1126/science.1092385

13. Fuchs TA, Brill A, Duerschmied D, Schatzberg D, Monestier M, Myers DD Jr, Wrobleski SK, Wakefield TW, Hartwig JH, Wagner DD (2010) Extracellular DNA traps promote thrombosis. Proc Natl Acad Sci USA 107(36):15880-15885. https://doi.org/10. 1073/pnas. 1005743107

14. Jorch SK, Kubes P (2017) An emerging role for neutrophil extracellular traps in noninfectious disease. Nat Med 23(3):279-287. https://doi.org/10.1038/nm.4294

15. Ikram MA, Brusselle G, Ghanbari M, Goedegebure A, Ikram MK, Kavousi M, Kieboom BCT, Klaver CCW, de Knegt RJ, Luik AI, Nijsten TEC, Peeters RP, van Rooij FJA, Stricker BH, Uitterlinden AG, Vernooij MW, Voortman T (2020) Objectives, design and main findings until 2020 from the Rotterdam Study. Eur J Epidemiol 35(5):483-517. https://doi.org/10.1007/s10654-020-00640-5

16. Kokame K, Nobe Y, Kokubo Y, Okayama A, Miyata T (2005) FRETS-VWF73, a first fluorogenic substrate for ADAMTS13 assay. Br J Haematol 129(1):93-100. https://doi.org/10.1111/j. 1365-2141.2005.05420.x

17. Mancini I, Valsecchi C, Palla R, Lotta LA, Peyvandi F (2012) Measurement of anti-ADAMTS13 neutralizing autoantibodies: a comparison between CBA and FRET assays. J Thromb Haemost 10(7):1439-1442. https://doi.org/10.1111/j.1538-7836.2012. 04744.x

18. Borissoff JI, Joosen IA, Versteylen MO, Brill A, Fuchs TA, Savchenko AS, Gallant M, Martinod K, Ten Cate H, Hofstra L, Crijns HJ, Wagner DD, Kietselaer B (2013) Elevated levels of circulating DNA and chromatin are independently associated with severe coronary atherosclerosis and a prothrombotic state.
Arterioscler Thromb Vasc Biol 33(8):2032-2040. https://doi.org/ 10.1161/ATVBAHA.113.301627

19. Heeringa J, van der Kuip DA, Hofman A, Kors JA, van Herpen G, Stricker BH, Stijnen T, Lip GY, Witteman JC (2006) Prevalence, incidence and lifetime risk of atrial fibrillation: the Rotterdam study. Eur Heart J 27(8):949-953. https://doi.org/10.1093/eurhe artj/ehi825

20. Aviles RJ, Martin DO, Apperson-Hansen C, Houghtaling PL, Rautaharju P, Kronmal RA, Tracy RP, Van Wagoner DR, Psaty BM, Lauer MS, Chung MK (2003) Inflammation as a risk factor for atrial fibrillation. Circulation 108(24):3006-3010. https://doi. org/10.1161/01.CIR.0000103131.70301.4F

21. Frustaci A, Chimenti C, Bellocci F, Morgante E, Russo MA, Maseri A (1997) Histological substrate of atrial biopsies in patients with lone atrial fibrillation. Circulation 96(4):1180-1184. https://doi.org/10.1161/01.cir.96.4.1180

22. Gould TJ, Lysov Z, Liaw PC (2015) Extracellular DNA and histones: double-edged swords in immunothrombosis. J Thromb Haemost 13(Suppl 1):S82-91. https://doi.org/10.1111/jth.12977

23. Wakili R, Voigt N, Kaab S, Dobrev D, Nattel S (2011) Recent advances in the molecular pathophysiology of atrial fibrillation. J Clin Invest 121(8):2955-2968. https://doi.org/10.1172/JCI46315

24. Dun W, Boyden PA (2009) Aged atria: electrical remodeling conducive to atrial fibrillation. J Interv Card Electrophysiol 25(1):918. https://doi.org/10.1007/s10840-008-9358-3

25. Dobaczewski M, Chen W, Frangogiannis NG (2011) Transforming growth factor (TGF)-beta signaling in cardiac remodeling. J Mol Cell Cardiol 51(4):600-606. https://doi.org/10.1016/j.yjmcc.2010. 10.033

26. Shen MJ, Choi EK, Tan AY, Han S, Shinohara T, Maruyama M, Chen LS, Shen C, Hwang C, Lin SF, Chen PS (2011) Patterns of baseline autonomic nerve activity and the development of pacinginduced sustained atrial fibrillation. Heart Rhythm 8(4):583-589. https://doi.org/10.1016/j.hrthm.2010.11.040

27. Korantzopoulos P, Kolettis T, Siogas K, Goudevenos J (2003) Atrial fibrillation and electrical remodeling: the potential role of inflammation and oxidative stress. Med Sci Monit 9(9):RA225-9

28. Korantzopoulos P, Letsas KP, Tse G, Fragakis N, Goudis CA, Liu $\mathrm{T}$ (2018) Inflammation and atrial fibrillation: a comprehensive review. J Arrhythm 34(4):394-401. https://doi.org/10.1002/joa3. 12077

29. Gupta DK, Shah AM, Giugliano RP, Ruff CT, Antman EM, Grip LT, Deenadayalu N, Hoffman E, Patel I, Shi M, Mercuri M, Mitrovic V, Braunwald E, Solomon SD (2014) Effective aNticoaGulation with factor $\mathrm{x}$ AnGiAFTIMIESI. Left atrial structure and function in atrial fibrillation: ENGAGE AF-TIMI 48. Eur Heart J 35(22):1457-1465. https://doi.org/10.1093/eurheartj/eht500

30. Henry WL, Morganroth J, Pearlman AS, Clark CE, Redwood DR, Itscoitz SB, Epstein SE (1976) Relation between echocardiographically determined left atrial size and atrial fibrillation. Circulation 53(2):273-279. https://doi.org/10.1161/01.cir.53.2.273

31. Kannel WB, Wolf PA, Castelli WP, D’Agostino RB (1987) Fibrinogen and risk of cardiovascular disease. The Framingham study. JAMA 258(9):1183-1186

32. Tsai HM (2007) Thrombotic thrombocytopenic purpura: a thrombotic disorder caused by ADAMTS13 deficiency. Hematol Oncol Clin North Am 21(4):609-632. https://doi.org/10.1016/j.hoc. 2007.06.003

33. Sonneveld MA, de Maat MP, Portegies ML, Kavousi M, Hofman A, Turecek PL, Rottensteiner H, Scheiflinger F, Koudstaal PJ, Ikram MA, Leebeek FW (2015) Low ADAMTS13 activity is associated with an increased risk of ischemic stroke. Blood 126(25):2739-2746. https://doi.org/10.1182/ blood-2015-05-643338

34. van Loon JE, de Maat MP, Hofman A, Witteman JC, Leebeek FW (2011) Relationship between thrombospondin gene variations, von 
Willebrand factor levels and the risk of coronary heart disease in an older population. J Thromb Haemost 9(7):1415-1417. https:// doi.org/10.1111/j.1538-7836.2011.04314.x

35. Schnabel RB, Larson MG, Yamamoto JF, Sullivan LM, Pencina MJ, Meigs JB, Tofler GH, Selhub J, Jacques PF, Wolf PA, Magnani JW, Ellinor PT, Wang TJ, Levy D, Vasan RS, Benjamin EJ (2010) Relations of biomarkers of distinct pathophysiological pathways and atrial fibrillation incidence in the community. Circulation 121(2):200-207. https://doi.org/10.1161/CIRCULATIO NAHA.109.882241

36. Adamsson Eryd S, Smith JG, Melander O, Hedblad B, Engstrom G (2011) Inflammation-sensitive proteins and risk of atrial fibrillation: a population-based cohort study. Eur J Epidemiol 26(6):449-455. https://doi.org/10.1007/s10654-011-9565-6

37. Alonso A, Tang W, Agarwal SK, Soliman EZ, Chamberlain AM, Folsom AR (2012) Hemostatic markers are associated with the risk and prognosis of atrial fibrillation: the ARIC study. Int J Cardiol 155(2):217-222. https://doi.org/10.1016/j.ijcard.2010.09.051

38. Mukamal KJ, Tolstrup JS, Friberg J, Gronbaek M, Jensen G (2006) Fibrinogen and albumin levels and risk of atrial fibrillation in men and women (the Copenhagen City Heart Study). Am J Cardiol 98(1):75-81. https://doi.org/10.1016/j.amjcard.2006.01. 067

39. Conen D, Ridker PM, Everett BM, Tedrow UB, Rose L, Cook NR, Buring JE, Albert CM (2010) A multimarker approach to assess the influence of inflammation on the incidence of atrial fibrillation in women. Eur Heart J 31(14):1730-1736. https://doi.org/10.1093/ eurheartj/ehq146

40. Issac TT, Dokainish H, Lakkis NM (2007) Role of inflammation in initiation and perpetuation of atrial fibrillation: a systematic review of the published data. J Am Coll Cardiol 50(21):20212028. https://doi.org/10.1016/j.jacc.2007.06.054

41. Ko D, Benson MD, Ngo D, Yang Q, Larson MG, Wang TJ, Trinquart L, McManus DD, Lubitz SA, Ellinor PT, Vasan RS, Gerszten RE, Benjamin EJ, Lin H (2019) Proteomics profiling and risk of new-onset atrial fibrillation: framingham heart study. J Am Heart Assoc 8(6):e010976. https://doi.org/10.1161/JAHA. 118.010976

42. Barac A, Campia U, Panza JA (2007) Methods for evaluating endothelial function in humans. Hypertension 49(4):748-760. https://doi.org/10.1161/01.HYP.0000259601.38807.a6

43. Mannucci PM (1998) von Willebrand factor: a marker of endothelial damage? Arterioscler Thromb Vasc Biol 18(9):1359-1362. https://doi.org/10.1161/01.atv.18.9.1359

44. Davignon J, Ganz P (2004) Role of endothelial dysfunction in atherosclerosis. Circulation 109(23 Suppl 1):III27-III32. https:// doi.org/10.1161/01.CIR.0000131515.03336.f8
45. Guo Y, Lip GY, Apostolakis S (2012) Inflammation in atrial fibrillation. J Am Coll Cardiol 60(22):2263-2270. https://doi.org/10. 1016/j.jacc.2012.04.063

46. Samman Tahhan A, Sandesara PB, Hayek SS, Alkhoder A, Chivukula K, Hammadah M, Mohamed-Kelli H, O’Neal WT, Topel M, Ghasemzadeh N, Ko YA, Aida H, Gafeer M, Sperling L, Vaccarino V, Liang Y, Jones DP, Quyyumi AA (2017) Association between oxidative stress and atrial fibrillation. Heart Rhythm 14(12):1849-1855. https://doi.org/10.1016/j.hrthm.2017.07.028

47. Esteve-Pastor MA, Roldan V, Rivera-Caravaca JM, RamirezMacias I, Lip GYH, Marin F (2019) The use of biomarkers in clinical management guidelines: a critical appraisal. Thromb Haemost 119(12):1901-1919. https://doi.org/10.1055/s-0039-16969 55

48. Camelo-Castillo A, Rivera-Caravaca JM, Marin F, Vicente V, Lip GYH, Roldan V (2020) Predicting adverse events beyond stroke and bleeding with the $\mathrm{ABC}$-stroke and $\mathrm{ABC}$-bleeding scores in patients with atrial fibrillation: the Murcia AF project. Thromb Haemost 120(8):1200-1207. https://doi.org/10.1055/s-00401712914

49. Linde C, Bongiorni MG, Birgersdotter-Green U, Curtis AB, Deisenhofer I, Furokawa T, Gillis AM, Haugaa KH, Lip GYH, Van Gelder I, Malik M, Poole J, Potpara T, Savelieva I, Sarkozy A, Group ESCSD (2018) Sex differences in cardiac arrhythmia: a consensus document of the European Heart Rhythm Association, endorsed by the Heart Rhythm Society and Asia Pacific Heart Rhythm Society. Europace 20(10):1565-ao. https://doi.org/10. 1093/europace/euy067

50. Westerman S, Wenger N (2019) Gender differences in atrial fibrillation: a review of epidemiology, management, and outcomes. Curr Cardiol Rev 15(2):136-144. https://doi.org/10.2174/15734 03X15666181205110624

51. Whitacre CC (2001) Sex differences in autoimmune disease. Nat Immunol 2(9):777-780. https://doi.org/10.1038/ni0901-777

52. Imahara SD, Jelacic S, Junker CE, O'Keefe GE (2005) The influence of gender on human innate immunity. Surgery 138(2):275282. https://doi.org/10.1016/j.surg.2005.03.020

53. Hayden H, Ibrahim N, Klopf J, Zagrapan B, Mauracher LM, Hell L, Hofbauer TM, Ondracek AS, Schoergenhofer C, Jilma B, Lang IM, Pabinger I, Eilenberg W, Neumayer C, Brostjan C (2021) ELISA detection of MPO-DNA complexes in human plasma is error-prone and yields limited information on neutrophil extracellular traps formed in vivo. PLoS One 16(4):e0250265. https://doi. org/10.1371/journal.pone.0250265

\section{Authors and Affiliations}

\section{Martijn J. Tilly ${ }^{1}$. Sven Geurts ${ }^{1}$. Samantha J. Donkel ${ }^{2}$ - M. Arfan Ikram ${ }^{1} \cdot$ Natasja M. S. de Groot ${ }^{3}$. Moniek P. M. de Maat $^{2} \cdot$ Maryam Kavousi $^{1}$ (])}

Maryam Kavousi

m.kavousi@erasmusmc.nl

1 Department of Epidemiology, Erasmus MC University Medical Center Rotterdam, Rotterdam, The Netherlands

2 Department of Hematology, Erasmus MC University Medical Center Rotterdam, Rotterdam, The Netherlands
3 Department of Cardiology, Erasmus MC University Medical Center Rotterdam, Office Na-2714, PO Box 2040, 3000 CA Rotterdam, The Netherlands 